\title{
Adipose tissue inflammation contributes to body weight loss induced by experimental chronic food allergy in mice
}

\author{
Denise Carmona Cara ${ }^{1 *}$, Luana PA Dourado², Mria LM Noviello², Debora M Alvarenga², Gustavo B Menezes², \\ Adaliene VM Ferreira ${ }^{3}$, Danielle G Souza ${ }^{4}$
}

From Food Allergy and Anaphylaxis Meeting 2011

Venice, Italy. 17-19 February 2011

Food allergy affects approximately $5 \%$ of children and $3 \%$ of the adult population in the western world. This disease is the manifestation of an abnormal immune response to antigens introduced into the organism orally and it is often mediated by IgE. Our group developed a chronic mouse model for the food allergy and one of the most remarkable alterations observed is a loss of body weight. However, the disturbances that trigger this loss of body weight are not clear. Thus, the purpose of this study was to investigate the mechanisms involved in weight loss of mice with ovalbumin-induced food allergy. With this purpose, BALB/c mice were subcutaneously sensitized with ovalbumin in aluminum hydroxide and challenged with the antigen containing diet for 7 days. The allergic mice showed significant weight loss with loss of adipose tissue, although it was not observed a reduction in food intake. These mice demonstrated adipose tissue inflammation characterized by increased leukocyte recruitment (visualized by intravital microscopy) and infiltration of mast cells, macrophages and regulatory $\mathrm{T}$ cells in the stroma. Moreover, we demonstrated high concentrations of TNF- $\alpha$, IL-6, IL-10 and the chemokine MCP-1/CCL-2 in this tissue. The metabolic changes in adipose tissue of allergic animals were represented by increased glucose uptake and lipolysis in adipocytes, resulting in atrophy of these cells. Changes were also seen in systemic metabolism characterized by decreased serum concentrations of glucose, triglycerides, total cholesterol and free fatty acids in allergic mice. Based on our results, we conclude that food allergy induces adipose tissue inflammation by producing

'Federal University of Minas Gerais- UFMG, Department of Morphology, Belo Horizonte, Brazil

Full list of author information is available at the end of the article mediators that lead to atrophy of this tissue. The decrease in adipose tissue mass has systemic consequences and results in loss of body weight.

\section{Author details}

${ }^{1}$ Federal University of Minas Gerais- UFMG, Department of Morphology, Belo Horizonte, Brazil. ${ }^{2}$ Federal University of Minas Gerais- UFMG, Morphology, Belo Horizonte, Brazil. ${ }^{3}$ Federal University of Minas Gerais- UFMG, Basic Nursing, Belo Horizonte, Brazil. ${ }^{4}$ Federal University of Minas Gerais- UFMG, Department of Microbiology, Belo Horizonte, Brazil.

Published: 12 August 2011

doi:10.1186/2045-7022-1-S1-O28

Cite this article as: Cara et al: Adipose tissue inflammation contributes to body weight loss induced by experimental chronic food allergy in mice. Clinical and Translational Allergy 2011 1(Suppl 1):O28.

Submit your next manuscript to BioMed Central and take full advantage of:

- Convenient online submission

- Thorough peer review

- No space constraints or color figure charges

- Immediate publication on acceptance

- Inclusion in PubMed, CAS, Scopus and Google Scholar

- Research which is freely available for redistribution

\section{() Biomed Central}

(c) 2011 Cara et al; licensee BioMed Central Ltd. This is an open access article distributed under the terms of the Creative Commons Attribution License (http://creativecommons.org/licenses/by/2.0), which permits unrestricted use, distribution, and reproduction in any medium, provided the original work is properly cited. 